\title{
Fibrinogen and von Willebrand factor in IDDM: relationships to lipid vascular risk factors, blood pressure, glycaemic control and urinary albumin excretion rate: the EURODIAB IDDM complications study
}

\author{
M. G reaves ${ }^{1}$, R. G. M alia ${ }^{2}$, K. G oodfellow ${ }^{2}$, M. Mattock ${ }^{3}$, L . K. Stevens ${ }^{4}$, J . M. Stephenson ${ }^{4}$, J . H . Fuller', \\ and the E U R O D IA B ID D M Complications Study G roup*
}

${ }^{1}$ Department of Medicine and Therapeutics, University of Aberdeen, Scotland, UK

${ }^{2}$ Department of Haematology, Royal Hallamshire Hospital, Sheffield, UK

${ }^{3}$ Department of Chemical Pathology, UMDS, St. Thomas's Hospital, London, UK

${ }^{4}$ Department of Epidemiology and Public Health, University College, London, UK

Summary The interrelationships between fibrinogen, von Willebrand factor, a marker of vascular endothelial cell damage, and serum lipids were explored in well-characterised subjects with insulin-dependent diabetes mellitus. The 2091 subjects were enrolled into a cross-sectional, clinic-based study of complications, from 16 European countries: the EURODIAB IDDM Complications study. The anticipated significant relationships between both plasma fibrinogen and plasma von Willebrand factor concentrations and age and glycaemic control, and between fibrinogen and body mass index, were noted. Fibrinogen, adjusted for age and glycated haemoglobin concentration, was also related to smoking habits and was higher in the quartiles with highest systolic and diastolic blood pressures. There was a clustering of vascular risk factors, with a positive relationship between plasma fibrinogen and serum triglyceride concentrations in both genders and between fibrinogen and total cholesterol in males. An inverse relationship between fibrinogen and high density lipoprotein cholesterol was also apparent in males. A prominent feature was a positive relationship between both fibrinogen and von Willebrand factor and albumin excretion rate $(p<0.001$ and $p<0.003$ respectively) in those with retinopathy but not in those without this complication. In view of previous observations on blood pressure and albuminuria in these subjects the findings are consistent with the hypothesis that microalbuminuria and increased plasma von Willebrand factor are due to endothelial cell perturbation in response to mildly raised blood pressure in subjects with retinopathy. Fibrinogen may also contribute to microvascular disease and its relationships to lipid vascular risk factors suggest a possible pathogenic role in arterial disease in diabetes. [Diabetologia (1997) 40: 698-705]

Keywords Fibrinogen, von Willebrand factor, albuminuria, insulin-dependent diabetes mellitus, vascular disease.
Received: 10 December 1996 and in revised form: 14 March 1997

Corresponding author: Dr. M. Greaves, Department of Medicine and Therapeutics, University of Aberdeen, Polwarth Building, Foresterhill, Aberdeen AB25 2ZD, UK

A bbreviations: AER, Albumin excretion rate; $\mathrm{Apo}_{\mathrm{A} 1}$, apolipoprotein-A1; BMI, body mass index; CVD, cardiovascular disease; ELISA, enzyme-linked immunosorbent assay; HDL, high density lipoprotein; IDDM, insulin-dependent diabetes mellitus; LDL, low density lipoprotein; vWF, von Willebrand factor.

* see acknowledgements
The pathogenic mechanisms underlying the development of microvascular complications in insulin-dependent diabetes mellitus (IDDM) remain obscure despite the fact that retinopathy develops in the majority [1-3], and nephropathy in around $30 \%[3,4]$. Although duration of diabetes and poor glycaemic control are established risk factors, they appear to account for only a proportion of an individual's risk [5]. We have recently demonstrated that, in subjects with retinopathy but not those without, mean urinary albumin excretion rate increases steeply when the mean diastolic blood pressure rises above $75 \mathrm{mmHg}$. It thus appears that members of a subgroup of diabetic subjects may have abnormal renal vulnerability 
to mildly raised blood pressure and that retinopathy is a close correlate of this risk [6].

von Willebrand factor (vWF) is synthesised by vascular endothelial cells and megakaryocytes and an increased concentration in plasma can serve as a marker of endothelial cell damage [7-9]. Such an increase is a feature of diabetic nephropathy [10]. Recent studies in small numbers of subjects with IDDM suggest that vWF is a sensitive marker of incipient nephropathy and that a rise in the plasma concentration may even precede the development of microalbuminuria $[11,12]$. Information regarding any relationship between vWF and retinopathy is, however, conflicting [13-15]. vWF is an essential component in platelet adhesion to subendothelium and a potential role in the pathogenesis of diabetic microvascular disease cannot be discounted [7].

Several epidemiological studies have confirmed the role of plasma fibrinogen as an independent risk factor for myocardial infarction and stroke in the general population [16-18]. Although microalbuminuria in diabetes predicts for an increased risk of cardiovascular death [19-21], the relationships between fibrinogen and microalbuminuria have only been studied in a limited number of subjects [22,23]. In addition, while complex interrelationships between plasma fibrinogen concentration and lifestyle and lipid riskfactors have been identified in population studies [24-27], these surveys included few IDDM patients.

The EURODIAB IDDM Complications Study is a cross-sectional clinic-based study of complications in randomly selected IDDM patients attending 31 clinics in 16 European countries which was established to measure the prevalence and severity of diabetic complications and to examine specific relations between putative risk factors [3]. In order to explore the potentially important interrelationships between a vascular risk factor for macrovascular disease, and a marker of endothelial cell damage, and complications in subjects with IDDM, we have included assays for plasma fibrinogen and vWF in the study programme.

\section{Subjects and methods}

Details of patient selection have been previously described (Eurodiab IDDM Complications Study Group, 1994). In summary, each centre selected a stratified random sample of patients attending the hospital in 1 year. IDDM was defined as onset before age 36 years with continuous insulin treatment initiated less than 1 year from diagnosis. From the entire study cohort of 3250 patients blood samples for analysis of haemostatic and lipid risk factors were available on 2091 (64\%). The demographic and clinical characteristics are listed in Table 1. The composition of the study group was representative of the entire cohort, there being no significant difference in any of the parameters listed. All centres were represented.

Albumin excretion rate (AER) was determined, from a timed 24-h urinary collection after exclusion of urinary infection, in a central laboratory by an immunoturbidometric
Table 1. Demographic and clinical characteristics of the patients

\begin{tabular}{|c|c|c|}
\hline & $\begin{array}{l}\text { Men } \\
n=1064\end{array}$ & $\begin{array}{l}\text { Women } \\
n=1027\end{array}$ \\
\hline Age (years) & $33.0 \pm 10.2$ & $32.8 \pm 10.1$ \\
\hline Duration (years) & $14.5 \pm 9.7$ & $15.0 \pm 9.3$ \\
\hline $\mathrm{HbA}_{1 \mathrm{c}}(\%)$ & $6.6 \pm 1.8$ & $6.7 \pm 1.9$ \\
\hline Body mass index $\left(\mathrm{kg} / \mathrm{m}^{2}\right)$ & $23.6 \pm 2.7$ & $23.5 \pm 3.2$ \\
\hline Systolic blood pressure $(\mathrm{mm} \mathrm{Hg})$ & $124.3 \pm 16.4$ & $119.0 \pm 18.4$ \\
\hline Diastolic blood pressure ( $\mathrm{mm} \mathrm{Hg}$ ) & $77.0 \pm 11.3$ & $74.0 \pm 11.4$ \\
\hline Total cholesterol $(\mathrm{mmol} / \mathrm{l})$ & $5.20 \pm 1.14$ & $5.5 \pm 1.12$ \\
\hline HDL-cholesterol (mmol/l) & $1.37 \pm 0.38$ & $1.62 \pm 0.44$ \\
\hline LDL-cholesterol ( $\mathrm{mmol} / \mathrm{l})$ & $3.34 \pm 0.98$ & $3.41 \pm 1.02$ \\
\hline Fasting triglyceride ${ }^{\mathrm{a}}(\mathrm{mmol} / \mathrm{l})$ & $1.03 \pm 3.59$ & $0.94 \pm 3.11$ \\
\hline Fibrinogen $(\mathrm{g} / \mathrm{l})$ & $3.07 \pm 0.93$ & $3.37 \pm 0.96$ \\
\hline \multirow[t]{2}{*}{ von Willebrand factor ${ }^{\mathrm{a}}(\mathrm{U} / \mathrm{l})$} & $1.09 \pm 3.79$ & $1.09 \pm 3.46$ \\
\hline & $\mathrm{n} \quad(\%)$ & $\mathrm{n} \quad(\%)$ \\
\hline Ex-smoker & $238(22)$ & $149(15)$ \\
\hline Current smoker & $368(35)$ & $291(28)$ \\
\hline Neuropathy present & $291(29)$ & $241(25)$ \\
\hline Microalbuminuria present & $244(24)$ & $190(19)$ \\
\hline Macroalbuminuria present & $109(11)$ & $84 \quad(8)$ \\
\hline Retinopathy present & $393(47)$ & $366(45)$ \\
\hline CVD present & $109(10)$ & $103(10)$ \\
\hline
\end{tabular}

${ }^{a}$ Geometric mean (range)

Data are mean \pm SD or $n(\%)$

method using goat anti-human albumin antiserum and human serum albumin standards. Microalbuminuria was defined as AER between 20 and $200 \mu \mathrm{g} / \mathrm{min}$. $\mathrm{HbA}_{1 \mathrm{c}}$ was measured in a central laboratory by immunoassay using monoclonal anti$\mathrm{HbA}_{1 \mathrm{c}}$. Plasma fibrinogen and vWF were also measured centrally on citrated plasma prepared from fresh blood obtained by venepuncture. Plasma samples were stored at less than -20 degrees $\mathrm{C}^{\circ}$ at all times until assay. Fibrinogen was assayed by a clotting assay based on the prothrombin time, on an Instrumentation Laboratories Series 300(R) Autoanalyser and vWF antigen by ELISA, as previously described [28]; a pooled plasma standard, calibrated against the UK (NIBSAC) standard, was employed. Hidden duplicate samples were included as a check on reproducibility. Satisfactory performance of these assays in UK National Quality Assurance schemes was recorded. Triglyceride, cholesterol and the cholesterol content of HDL were determined on fasting serum, after manganese and heparin precipitation, by standard enzymatic techniques; LDL cholesterol was calculated.

Presence of cardiovascular disease (CVD) was assessed by the clinical history of myocardial infarction, angina pectoris, stroke or coronary artery bypass graft surgery, and by Minnesota-coding of 12-lead resting ECGs [29]. Sitting blood pressure was measured to the nearest $2 \mathrm{mmHg}$. with a random zero sphygmomanometer after 5 min of rest; the mean of two readings was used for analysis. Retinopathy was assessed from photographs of two retinal fields per eye graded by a single observer, as previously described [30].

\section{Statistical analysis}

To examine the association of fibrinogen and vWF with other risk factors for diabetes complications and also with the diabetes complications themselves, for each variable, analysis of covariance was used, to calculated age and $\mathrm{HbA}_{1 \mathrm{c}}$ adjusted mean levels of the haemostatic variables within each category, and the adjusted means were compared across categories. For continuous variables these categories were defined using the 
Table 2. Relationship of fibrinogen and von Willebrand factor with age, $\mathrm{HbA}_{1 \mathrm{c}}$ and body mass index by sex

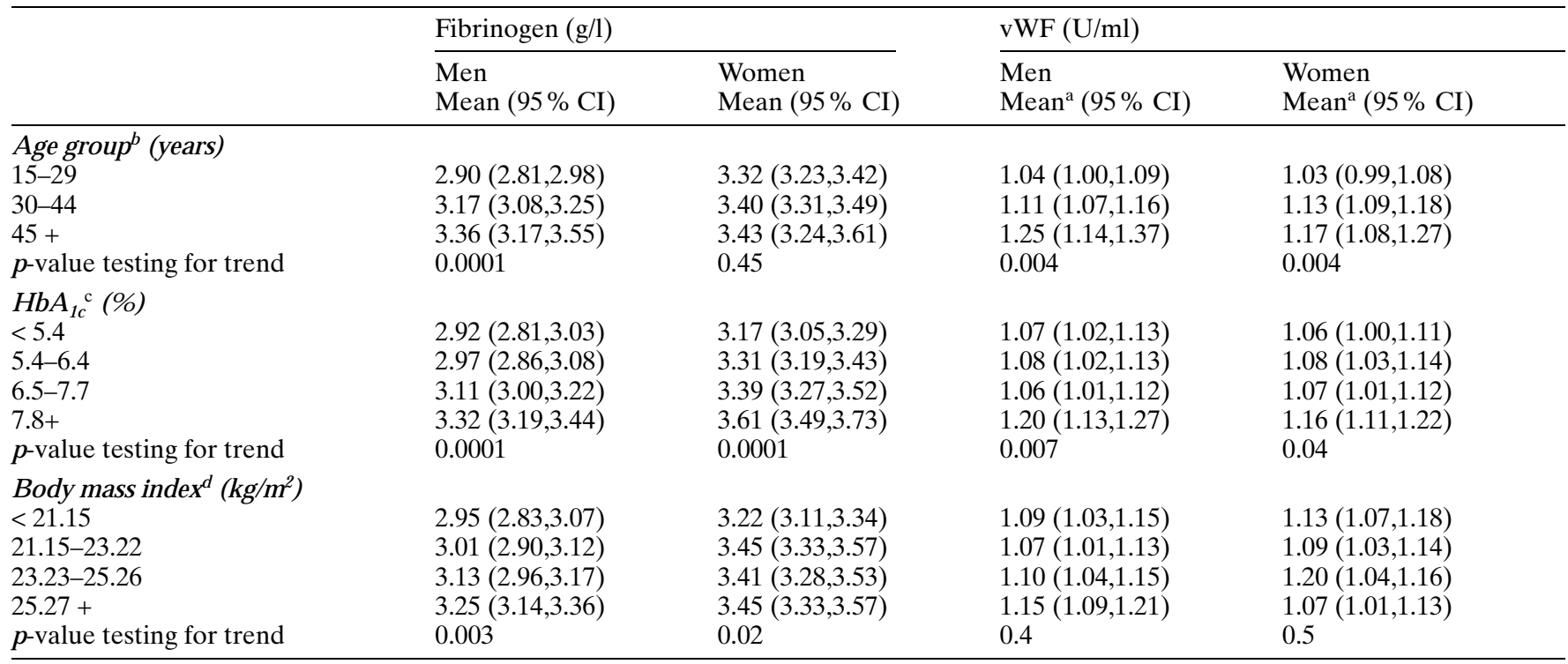

${ }^{\mathrm{a}}$ Geometric mean; ${ }^{\mathrm{b}}$ Means are adjusted for $\mathrm{HbA}_{1 \mathrm{c}}$ and duration; ${ }^{\mathrm{c}}$ Means are adjusted for age and duration; ${ }^{\mathrm{d}}$ Means are adjusted for age and $\mathrm{HbA}_{1 \mathrm{c}} ; \mathrm{CI}$, Confidence interval

Table 3. Mean values of fibrinogen and vWF adjusted for age/ $\mathrm{HbA}_{1 \mathrm{c}}$ by blood pressure and smoking habits

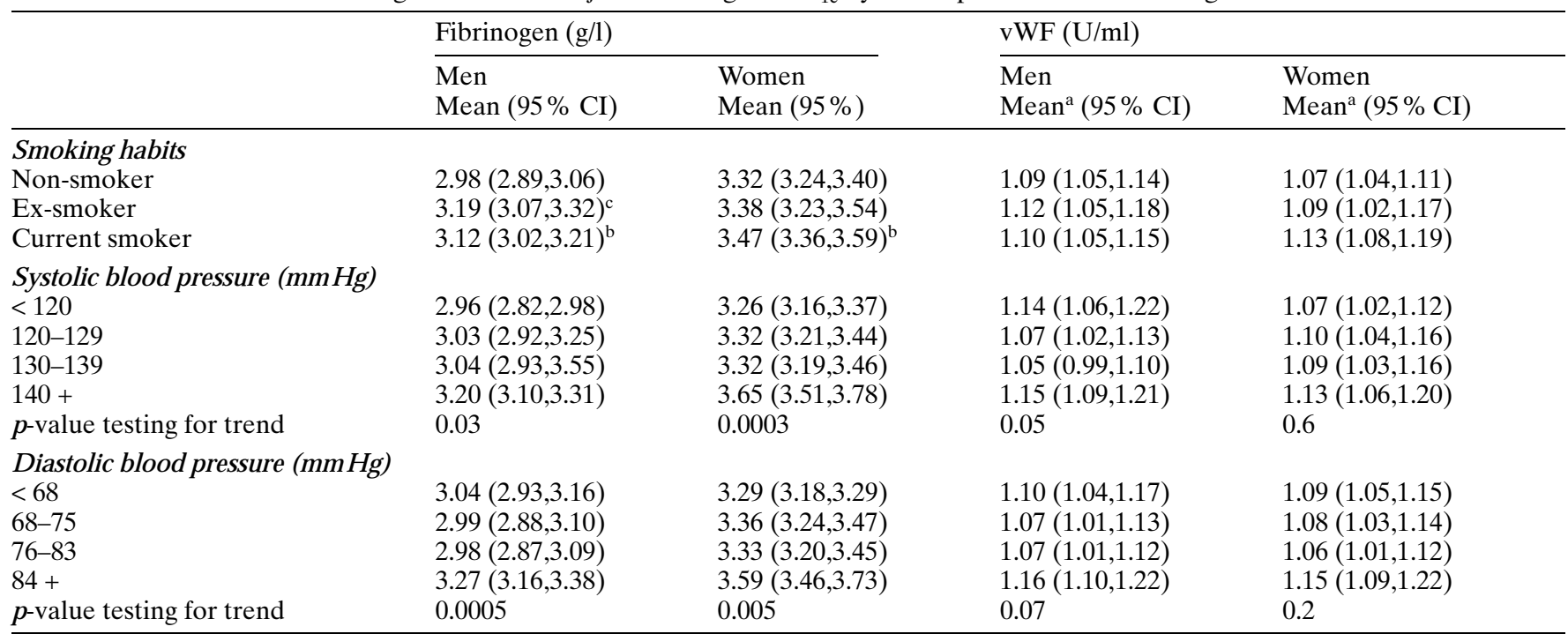

${ }^{\mathrm{a}}$ Geometric mean; Significantly different to non-smokers with ${ }^{\mathrm{b}} \mathrm{p}<0.05 ;{ }^{\mathrm{c}} \mathrm{p}<0.01$

quartiles of the distribution for the variable, with the exception of age where the stratification implemented in the selection of the EURODIAB sample was used [3]. Analysis of variance was also used to assess the significance of the interaction of retinopathy with fibrinogen and vWF. For any analyses that included vWF, albumin excretion and fasting triglyceride as continuums, because of the skewness of their distributions, the variables were logged and geometric means quoted.

\section{Results}

The expected strong relationships between age and both fibrinogen and vWF were confirmed, although this was confined to males in the case of fibrinogen
(Table 2). Plasma fibrinogen and vWF, adjusted for age, were also strongly related to glycaemic control and fibrinogen rose with increasing body mass index (BMI;Table 2). Compared with non-smokers, ageand $\mathrm{HbA}_{1 \mathrm{c}}$-adjusted mean fibrinogen was significantly higher in current smokers for both genders and only in men higher in ex-smokers (Table 3). No such relationships were found in the case of vWF. A relationship was apparent between both systolic and diastolic blood pressure and adjusted fibrinogen, but not vWF, concentrations (Table 3). Although the prevalence of CVD was highest in the quartile with highest adjusted fibrinogen values in both males and females the trend did not achieve statistical 
Table 4. Mean values of fibrinogen and vWF adjusted for age, $\mathrm{HbA}_{1 \mathrm{c}}$ and $\mathrm{BMI}$ by lipids/lipoproteins

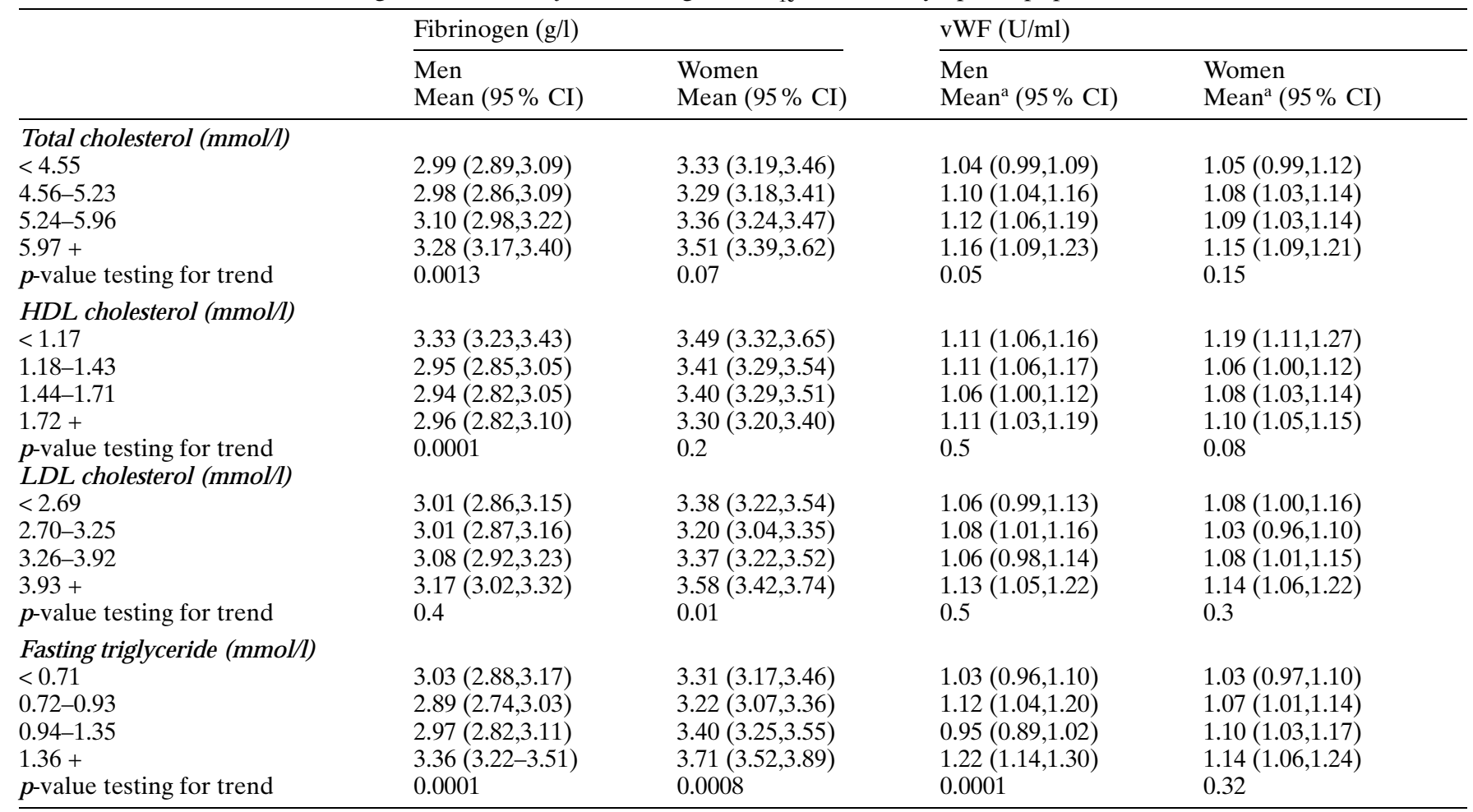

a Geometric mean

Table 5. Mean values of fibrinogen and $\mathrm{vWF}$ adjusted for age/ $\mathrm{HbA}_{1 \mathrm{c}}$ by albumin excretion and neuropathy

\begin{tabular}{|c|c|c|c|c|}
\hline & \multicolumn{2}{|l|}{ Fibrinogen $(\mathrm{g} / \mathrm{l})$} & \multicolumn{2}{|l|}{$\mathrm{vWF}(\mathrm{U} / \mathrm{ml})$} \\
\hline & $\begin{array}{l}\text { Men } \\
\text { Mean }(95 \% \text { CI })\end{array}$ & $\begin{array}{l}\text { Women } \\
\text { Mean }(95 \% \text { CI })\end{array}$ & $\begin{array}{l}\text { Men } \\
\text { Mean }^{\mathrm{a}}(95 \%)\end{array}$ & $\begin{array}{l}\text { Women } \\
\operatorname{Mean}^{\mathrm{a}}(95 \% \mathrm{CI})\end{array}$ \\
\hline $\begin{array}{l}\text { R etinopathy } \\
\text { Absent } \\
\text { Present } \\
\text { p-value testing for difference }\end{array}$ & $\begin{array}{l}3.02(2.94,3.11) \\
3.08(2.99,3.17) \\
0.38\end{array}$ & $\begin{array}{l}3.29(3.20,3.38) \\
3.45(3.35,3.55) \\
0.03\end{array}$ & $\begin{array}{l}1.11(1.06,1.16) \\
1.06(1.02,1.11) \\
0.17\end{array}$ & $\begin{array}{l}1.08(1.04,1.13) \\
1.06(1.01,1.10) \\
0.44\end{array}$ \\
\hline
\end{tabular}

a Geometric mean

Significantly different to group where AER $<20 \mathrm{mg} / \mathrm{min}$ with ${ }^{\mathrm{b}} \mathrm{p}<0.01$; $^{\mathrm{c}} \mathrm{p}<0.001$

significance. Mean age and $\mathrm{HbA}_{1 \mathrm{c}}$ adjusted fibrinogen $(95 \%$ confidence interval $(\mathrm{CI}), \mathrm{g} / \mathrm{l})$ : in men with CVD $3.18(2.99,3.37)$ and without CVD 3.06 (3.00, $3.12), p=0.16$; in women with CVD $3.50(3.31,3.70)$ and without CVD $3.36(3.29,3.42), p=0.24$. There was no significant relationship between $\mathrm{vWF}$ and CVD. Mean age and $\mathrm{HbA}_{1 \mathrm{c}}$ adjusted vWF $(95 \% \mathrm{CI}$, $\mathrm{U} / \mathrm{ml})$ : in men with CVD $1.12(1.03,1.23)$ and without CVD 1.10 (1.07, 1.13), $p=0.6$; in women with CVD $1.06(0.97,1.15)$ and without CVD $1.10(1.07,1.13)$, $p=0.38$. The results of an analysis of fibrinogen and
vWF, adjusted for age, $\mathrm{HbA}_{1 \mathrm{c}}$ and body mass index, in relation to the lipid parameters are presented for males and females separately in Table 4; it is apparent that a higher level of total cholesterol and lower level of HDL cholesterol is accompanied by a higher fibrinogen concentration in males. Fibrinogen is significantly related to LDL cholesterol in females. There is also a positive relationship between fibrinogen and triglyceride in both genders. vWF is only weakly related to lipid parameters, being significantly related to fasting triglyceride in males only. 

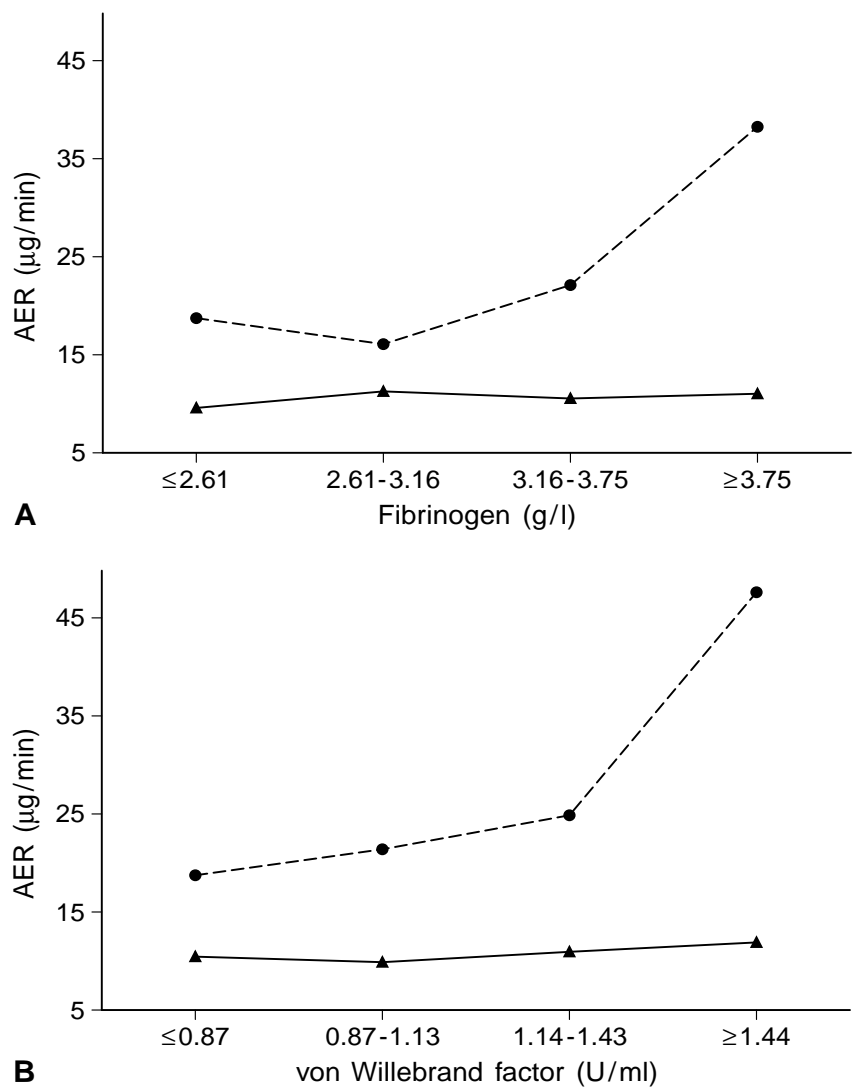

Fig. 1 (A , B ) Geometric mean albumin excretion rate by (A ) fibrinogen and (B) von Willebrand factor and retinopathy $(-0)$ or no retinopathy $(\boldsymbol{\Delta} \mathbf{\Delta})$, adjusted for age, $\mathrm{HbA}_{1 \mathrm{c}}$, total cholesterol, triglyceride, systolic blood pressure, smoking and BMI. The interaction of retinopathy with fibrinogen and von Willebrand factor gave a significance of $p<0.001$ in both cases

Higher concentrations of adjusted fibrinogen were found in males and females with neuropathy, and of vWF in females with this complication (Table 5).

There was no difference in haemostatic measures between those with microalbuminuria and those with normoalbuminuria, but subjects with AER of more than $200 \mu \mathrm{g} / \mathrm{min}$ had significantly higher plasma fibrinogen and vWF (Table 5). A marked interaction was apparent across the range of AER values with both vWF and fibrinogen in the group with retinopathy, which was not apparent in those without this complication (Fig. 1).

\section{Discussion}

In this extensive study of subjects with IDDM we have found relationships between plasma fibrinogen concentration and age, body mass index, and smoking habit which are comparable to those described in the general population [24-27]. In addition there appears to be a clustering of vascular risk factors, including raised fibrinogen, total and LDL cholesterol, triglyceride and blood pressure and reduced HDL cholesterol, in IDDM. Comparable relationships between lipid risk factors and fibrinogen have been reported in hyperlipidaemia [31] and similar findings described in cross-sectional studies in the general population [25]. Although the underlying mechanism remains unexplained, a role for non-esterified fatty acids in hepatic fibrinogen synthesis has been postulated [32], and we have reported a correlation between plasma concentrations of $\mathrm{Apo}_{\mathrm{A} 1}$ and fibrinogen in IDDM [33]. Despite this clustering of risk factors no significant relationship was found between fibrinogen and symptomatic and electrocardiographic evidence of CVD in this diabetic population. This is probably due to the relatively imprecise methods employed for assessment of the presence of atheromatous disease [29] and it is likely that the follow-up study, in which death and non-fatal myocardial infarction are used as end-points, will clarify any relationship.

In view of previous studies indicating that, in IDDM, those who develop clinical proteinuria have a much increased risk of premature cardiovascular complications $[34,35]$ we were interested to study the relationships between albuminuria and $\mathrm{vWF}$, a marker of vascular endothelial cell damage. Injury to the vascular endothelium appears to be central to the pathogenesis of atherosclerosis and may be an initiating event. Endothelial dysfunction is also a feature of diabetic nephropathy, even during the subclinical phase. Evidence for this includes the observation that the transcapillary escape rate of albumin is increased [36], and vasoconstrictor responses are blunted [37] in diabetic subjects with albuminuria. In addition the plasma concentrations of several peptides and proteins which are secreted by vascular endothelium, including plasminogen activator inhibitor (PAI) 1 [38] endothelin [39] and $\mathrm{vWF}$ [11] have been found to be increased in the presence of microalbuminuria. Indeed Stehouwer et al. [12] reported that, in six subjects, the increase in plasma vWF preceded and may therefore predict the development of microalbuminuria in IDDM. Clinical proteinuria without retinopathy is uncommon, but severe retinopathy with normal AER is a frequent finding in IDDM [6], suggesting that different pathogenetic mechanisms may be operating; it is noteworthy that data on plasma vWF in retinopathy are conflicting $[14,15]$.The results of the current study of over 2000 carefully clinically characterised subjects demonstrate a strong interaction between AER and vWF only in those with retinopathy, this being highly reminiscent of the relationships between blood pressure, AER and retinopathy in the same population [6]. There was, however, only a weak, or no, significant direct relationship between vWF and blood pressure. A plausible interpretation of these data is that, in the subgroup of patients who develop nephropathy in association with an increased renal vulnerability to modest increases in blood pressure, the renal vasculopathy is mediated through endothelial damage, and this is 
consistent with the hypothesis that microalbuminuria and release of $\mathrm{vWF}$ are responses to mildly raised blood pressure in subjects with retinopathy. Although those patients with clinical nephropathy had significantly higher plasma vWF concentrations than those with no albuminuria we were unable to confirm a similar increased level in association with microalbuminuria, a finding consistent with some [10], but not other [11], smaller studies. The patients enrolled in the EURODIAB Study are likely to be more representative of the overall diabetic population than has been the case in some more limited investigations, and the possible predictive value of vWF measurement will be better determined from follow-up data which will accrue after 5 years from recruitment.

There was also a marked interaction between fibrinogen and AER in diabetic patients with retinopathy which persisted after adjustment for confounding variables. It has long been recognised that plasma fibrinogen concentration is elevated in diabetes [40] but a relationship with nephropathy has not always been apparent [41]. Fibrinogen could contribute to the development of nephropathy in a variety of ways: it is the substrate for thrombin in blood coagulation, and animal studies indicate that the fibrinogen concentration at the initiation of coagulation influences the amount of fibrin deposited [42]; in this context it is relevant that low-dose heparin therapy was recently shown to reduce urinary albumin excretion rate in IDDM [43]. Fibrinogen is also an essential cofactor in platelet activation, and aggregability is influenced by the fibrinogen concentration in plasma [44]. Involvement of platelets and blood hypercoagulability in the pathogenesis of diabetic nephropathy has been postulated $[45,46]$. An alteration in glomerular haemodynamics has long been considered to be of pathophysiological importance in diabetic nephropathy and therefore the contribution of fibrinogen to the viscosity of blood may be of relevance. Furthermore, LDL cholesterol makes an equivalent contribution to viscosity [47] and our data indicate that this is also increased in the plasma of diabetic subjects, in close parallel with fibrinogen. In IDDM blood viscosity is higher in those with microvascular complications than in those without [33], and, in a morphological study of human diabetic neuropathy, which may also have a microvascular pathogenesis $[48,49]$, we previously demonstrated a strong association between plasma fibrinogen concentration and sural nerve capillary basement membrane thickness [28]. In the current study fibrinogen levels were also significantly higher in diabetic patients with neuropathy. It is noteworthy that renal and nerve damage have been found to be associated in diabetes [50]. Our finding of higher levels of vWF in females with diabetic neuropathy is also of interest, in view of the recent suggestion that plasma vWF concentration predicts progression of neuropathy in IDDM [51].
While changes in fibrinogen and vWF may not be causal in the vascular damage of diabetic microangiopathy, they could contribute through their effects on platelets, coagulability and viscosity, forming part of a self-propagating series of events leading to further endothelial damage and dysfunction. Although both fibrinogen and vWF are acute phase response proteins, this would not necessarily preclude a pathogenetic role in diabetic microvascular disease, for the above reasons, and as an explanation for the increased levels this mechanism is inconsistent with previous observations, where plasma C-reactive protein and vWF were not related in diabetes [14], nor in the vasculitides [52]. Regarding fibrinogen, the interrelationships with lipid parameters in the current and previous studies have not been linked to a reactive state, although recent data do suggest an association between lipid vascular risk factors, fibrinogen and C-reactive protein [53]. Restriction length polymorphisms which are associated with variation in fibrinogen levels have been identified [54] although the size of the genetic contribution to fibrinogen level is unclear. As there is evidence for a genetic predisposition to the development of diabetic nephropathy $[55,56]$, it is of interest to speculate that this may operate through fibrinogen or, perhaps, vWF.

The findings reported here support the hypothesis of a role for fibrinogen and vWF in vascular complications of IDDM and provide the basis for a valuable prospective follow-up study which will indicate the predictive value of fibrinogen and vWF in the development of CVD and other complications in diabetes.

A cknowledgements. We thank all the patients who took part in the study. The study was part of the EURODIAB Concerted Action Programme financially supported by the Commission of the European Communities. Additional financial support was received from ICI UK, Fidia, Bayer, Miles-Ames, Novo Nordisk and Pfizer.

\section{EURODIAB investigators:}

B. Karamanos, C. Tountas, A. Kofinis, K. Petrou, N. Katsilambros, Hippokration Hospital, Athens, Greece.

R. Giorgino, M. Cignarelli, M. L. De Cicco, I. Ramunni, Istituto di Clinica Medica, Endocrinologia e Malattie Metaboliche, Universita di Bari, Bari, Italy.

C. Ionescu-Tirgoviste, C. M. Iosif, D. Pitei, S. Buligescu, Clinic of Diabetes, Nutrition and Metabolic Diseases, Bucharest, Romania.

G. Tamas, Z. Kerenyi, A. M. Ahmed, J. Toth, P. Kempler, Tetenyi Teaching Hospital and Semmelweis University, Budapest, Hungary.

Se. Muntoni, M. Songini*, M. Stabilini, M. Fossarello*, S. Pintus*, Sä. Muntoni, Centro Malatti Dismetaboliche and *Ospedale San Michele, Cagliari, Italy.

J. B. Ferriss, C. C. Cronin, A. E. Whyte, P.E. Cleary, Cork Regional Hospital, Cork, Ireland.

M. Toeller, A. Klischan, T. Forst, F. A. Gries, Diabetes Forschungsinstitut, Universitat Dusseldorf, Germany.

R. Rottiers, H. Priem, University Hospital of Gent, Belgium. 
P. Ebeling, M. Sinisalo, V.A. Koivisto, University Hospital of Helsinki, Finland.

B. Idzior-Walus, B. Solnica, L. Szopinska-Ciba, K. Solnica, University School of Medicine, Krakow, Poland.

H. M. J. Krans, H. H. P. J. Lemkes, J. J. Jansen, J. Brachter, University Hospital of Leiden, The Netherlands.

J. Nunes-Correa, J. Boavida, Portuguese Diabetic Association, Lisbon, Portugal.

G. Michel, R. Wirion, Centre Hospitalier, Luxembourg.

A. J. M. Boulton, H. Ashe, D. J. S. Fernando, Manchester Royal Infirmary, UK.

G. Pozza, G. Slaviero, G. Comi, B. Fattor, F. Bandello, Ospedale San Raffaele, Milan, Italy.

H. U. Janka, A. Nuber, H. Mehnert, City Hospital Schwabing, Munich, Germany.

D. Ben Soussan, M.-C. Fallas, P. Fallas, Centre Hospitalier de Valenciennes, France.

E. Jepson, S. McHardy-Young, Central Middlesex Hospital, and J.H. Fuller, D. J. Betteridge, M. Milne, University College Hospital, NW London.

G. Crepaldi, R. Nosadini, T. Segato, E. Midena, M. R. Cipollina, D. Fedele, Istituto di Medicina Interna, Padua, Italy.

G. Cathelineau, B. Villatte Cathelineau, M. Jellal, N. Grodner, P. Gervais Feiss, Hospital Saint-Louis, Paris, France.

F. Santeusanio, G. Rosi, M. R. M. Ventura, C. Cagini, C. Marino, Istituto di Patologia Medica, Policlinico, Perugia, Italy.

R. Navalesi, G. Penno, R. Miccoli, M. Nannipieri, S. Manfredi, Istituto di Clinica Medica II, Pisa, Italy.

G. Ghirlanda, P. Cotroneo, A. Manto, C. Teodonio, A. Minnella, Universita Cattolica del Sacro Cuore, Rome, Italy.

J. D. Ward, S. Tesfaye, C. Mody, C. Rudd, Royal Hallamshire Hospital, Sheffield, UK.

G. M. Molinatti, F. Vitelli, M. Porta, G.F. Pagano, P. Cavallo Perin, P. Estivi, R. Sivieri, Q. Carta, G. Petraroli, Clinica Medica B, Patologia Medica, Ospedale Molinette, and Ospedale "Agnelli", Turin, Italy.

N. Papazoglou, G. Manes, G. Triantaphyllou, A. Ioannides, G. Skazagar, I. Kontogiannis, General Hospital of Thessaloniki, Greece.

M. Muggeo, V. Cacciatori, F. Bellavere, P. Galante, M. L. Gemma, Cattedra di Malattie del Metabolismo, Verona, Italy.

K. Irsigler, H. Abrahamian, C. Gurdet, B. Hornlein, C. Willinger, Hospital Vienna Lainz, Austria.

S. Walford, E. V. Wardle, S. Hughes, New Cross Hospital, Wolverhampton, UK.

G. Roglic, Z. Resman, Z. Metelko, Z. Skrabalo, Vuk Vrhovac Institute for Diabetes, Zagreb, Croatia.

Steering Committee Members: J.H. Fuller (London), H. Keen, Chairman (London), H. M. J. Krans (Leiden), R. Navelesi (Pisa), A.-K. Sjolie (Aarhus), J.M. Stephenson (London), M. Toeller (Dusseldorf), G.-C. Viberti (London), J. Ward (Sheffield).

Co-ordinating Centre: J.H. Fuller, J. Stephenson, T. Partridge, M. Milne, U.C.L. Medical School, UK.

Central Laboratories: W. G. John, The Royal London Hospital, and G.-C. Viberti, M. Mattock, A. Collins, A. Dredge, R. Sharp, Guy's Hospital, London, UK.

Retinopathy Co-ordination: A.-K. Sjolie, Aarhus University Hospital, Denmark.

Retinopathy Grading Centre: E. Kohner, S. Aldington, S. Cockley, Hammersmith Hospital, London, UK.

\section{References}

1. Klein R, Klein BEK, Moss SE, Davis MD, DeMets DL (1984) The Wisconsin Epidemiologic Study of diabetic retinopathy II. Prevalence and risk of diabetic retinopathy when age at diagnosis is less than thirty years. Arch Ophthalmol 102: 527-532

2. Orchard TJ, Dorman JS, Maser RE et al. (1990) Prevalence of complications in IDDM by sex and duration. Pittsburgh Epidemiology of Diabetes Complications Study II. Diabetes 39: 1116-1124

3. The EURODIAB IDDM Complications Study Group (1994) Microvascular and acute complications in IDDM patients: the EURODIAB IDDM Complications Study. Diabetologia 37: 278-285

4. Andersen AR, Christiansen JS, Andersen JK, Kreiner S, Deckert T (1983) Diabetic nephropathy in type 1 (insulindependent) diabetes: an epidemiological study. Diabetologia 25: 496-501

5. Wang PH, Lau J, Chalmers TC (1993) Meta-analysis of effects of intensive blood glucose control on late complications of type 1 diabetes. Lancet 341: 1306-1309

6. Stephenson JM, Fuller JH, Viberti G-C, Sjolie A-K, Navalesi R (1995) The EURODIAB IDDM Complications Study Group. Blood pressure, retinopathy and urinary albumin excretion in IDDM: the EURODIAB IDDM Complications Study. Diabetologia 38: 599-603

7. Greaves M, Preston FE (1984) Haemostatic abnormalities in diabetics. In: Jarrett RJ (ed) Diabetes and heart disease. Elsevier, Amsterdam, 2: 47-84

8. Greaves M, Pickering C, Knight G et al. (1987) Changes in the factor VIII complex in diabetic ketoacidosis; evidence of endothelial cell damage. Diabetologia 30: 160-165

9. van de Loo J (1995) Circulating factors of the haemostatic systems as indicators of increased or reduced coronary risk. Br J Haematol 91: 777-782

10. Jensen T, Bjerre-Knudsen J, Feldt-Rasmussen B, Deckert T (1989) Features of endothelial dysfunction in early diabetic nephropathy. Lancet 1: 461-463

11. Stehouwer CDA, Stroes ESG, Hackeng WHL, Mulder PGH, Den Ottolander GJH (1991) von Willebrand factor and development of diabetic nephropathy in IDDM. Diabetes 40: 971-976

12. Stehouwer CDA, Fischer HRA, van Kuijk AWR, Polak BCP, Donker AJM (1995) Endothelial dysfunction precedes development of microalbuminuria in IDDM. Diabetes 44: 561-564

13. Coller BS, Frank RN, Milton RC, Grabnick HR (1978) Plasma cofactors of platelet function: correlation with diabetic retinopathy and haemoglobins $\mathrm{A}_{1 \mathrm{a}-\mathrm{c}}$. Ann Intern Med 88: 311-316

14. Petty RG, Pottinger BE, Greenwood RM, Pearson JD, Mahler RF (1991) Diabetes is associated with a high incidence of endothelial-binding antibodies which do not correlate with retinopathy, von Willebrand factor, angiotensin-converting enzyme or C-reactive protein. Diabetes Res 17: 115-123

15. Stehouwer CDA, Zellenrath P, Polak BCP et al. (1992) von Willebrand factor and early diabetic retinopathy: no evidence for a relationship in patients with type 1 (insulin-dependent) diabetes mellitus and normal urinary albumin excretion. Diabetologia 35: 555-559

16. Meade TW, Mellows S, Brozovic M et al. (1986) Haemostatic function and ischaemic heart disease: principle results of the Northwick Park Heart Study. Lancet 2: 533-537

17. Kannel WB, DÁgostino RB, Belanger AJ (1987) Fibrinogen, cigarette smoking, and risk of cardiovascular disease: insights from the Framingham Study. Am Heart J 113: 1006-1010

18. Wilhelmsen L, Svardsudd K, Korsan-Bengtsen K et al. (1984) Fibrinogen as a risk factor for stroke and myocardial infarction. New Engl J Med 311: 501-505 
19. Jarrett RJ, Viberti G-C, Argyropoulos A et al. (1984) Microalbuminuria predicts mortality in non-insulin-dependent diabetes. Diabet Med 1: 17-19

20. Mogensen CE (1984) Microalbuminuria predicts clinical proteinuria and early mortality in maturity-onset diabetes. N Engl J Med 310: 356-360

21. Mattock MB, Keen H, Viberti G-C et al. (1988) Coronary heart disease and urinary albumin excretion rate in type 2 (non-insulin-dependent) diabetic patients. Diabetologia 31: $82-87$

22. Jones SL, Close CF, Mattock MB, Jarrett RJ, Keen H, Viberti GC (1989) Plasma lipid and coagulation factor concentrations in insulin-dependent diabetics with microalbuminuria. BMJ. 298: 487-490

23. Lee AJ, Lowe GDO, Woodward M, Tunstall-Pedoe H (1993) Fibrinogen in relation to personal history of prevalent hypertension, diabetes, stroke, intermittent claudication, coronary heart disease and family history: the Scottish Heart Health Study. Br Heart J 69: 338-342

24. Lee AJ, Smith WCS, Lowe GDO et al. (1990) Plasma fibrinogen and coronary risk factors: the Scottish Heart Health Study. J Clin Epidemiol 43: 913-919

25. Folsom AR, Conlan MG, Davis CE, Wu KK (1992) Relations between hemostasis variables and cardiovascular risk factors in middle-aged adults. Ann Epidemiol 2: 481-494

26. Eliasson M, Evrin PE, Lundblad DE (1994) Fibrinogen and fibrinolytic variables in relation to anthropometry, lipids and blood pressure. The Northern Sweden MONICA Study. J Clin Epidemiol 47: 513-524

27. Barasch E, Benderly M, Graff E et al. (1995) Plasma fibrinogen levels and their correlates in 6457 coronary heart disease patients. The Bezafibrate Infarction Prevention (BIP) Study. J Clin Epidemiol 48: 757-765

28. Ford I, Malik RA, Newrick PG, Preston FE, Ward JD, Greaves M (1992) Relationships between haemostatic factors and capillary morphology in human diabetic neuropathy. Thromb Haemost 68: 628-633

29. Koivisto VA, Stevens LK, Mattock M et al. (1996) Cardiovascular disease and its risk factors in insulin-dependent diabetes in Europe. Diabetes Care 19: 689-697

30. Aldington SJ, Kohner EM, Meuer S, Sjolie A-K, The EURODIAB IDDM Complications Study Group (1995) Methodology for retinal photography and assessment of diabetic retinopathy: the EURODIAB IDDM Complications Study. Diabetologia 38: 437-444

31. Lowe GDO, Drummond MM, Third JLHC et al. (1980) Increased plasma fibrinogen and platelet-aggregates in type II hyperlipoproteinaemia. Thromb Haemost 42: 1503-1507

32. Pilgeram LO, Pickart LR (1968) Control of fibrinogen biosynthesis: the role of free fatty acid. J Atheroscler Res 8: 155-156

33. Ford I, Dent MT, Greaves M, Preston FE, Wilson RM, Ward JD (1991) Correlation of haemostatic and rheological factors with apoproteins in early type 1 diabetes. Thromb Haemost 65: 56

34. Borch-Johnsen K, Kragh Andersen P, Deckert T (1985) The effect of proteinuria on relative mortality in type 1 (insulindependent) diabetes mellitus. Diabetologia 28: 590-596

35. Krolewski AS, Warram JH, Christlieb AR, Busick EJ, Kahn CR (1985) The changing natural history of nephropathy in type 1 diabetes. Am J Med 78: 785-794

36. Feldt-Rasmussen B(1986) Increased transcapillary escape rate of albumin in type 1 (insulin-dependent) diabetic patients with microalbuminuria. Diabetologia 29: 282-286

37. Elliot TG, Cockcroft JR, Groop PH, Viberti GC, Ritter JM (1993) Inhibition of nitric oxide synthesis in forearm vasculature of insulin-dependent diabetic patients: blunted vasoconstriction in patients with microalbuminuria. Clin Sci 85: 687-693

38. Gruden G, Cavallo-Perin P, Bazzan M, Stella S, Vuolo A, Pagano G (1994) PAI-1 and factor VII activity are higher in insulin-dependent diabetes mellitus patients with microalbuminuria. Diabetes 43: 426-429

39. Collier A, Leach JP, McLellan A, Jardine A, Morton JJ, Small M (1992) Plasma endothelinlike immunoreactivity levels in insulin-dependent diabetes mellitus patients with microalbuminuria. Diabetes Care 15: 1038-1040

40. Fuller JH, Keen H, Jarrett RJ et al. (1979) Haemostatic variables associated with diabetes and its complications. BMJ 2: 964-966

41. Jay RH, Jones SL, Hill CE et al. (1991) Blood rheology and cardiovascular risk factors in type 1 diabetes: relationship with microalbuminuria. Diabet Med 8: 662-667

42. Chooi CC, Gallus AS (1989) Acute phase reaction, fibrinogen level and thrombus size. Thromb Res. 53: 493-501

43. Myrup B, Hansen PM, Jensen Tet al. (1995) Effect of lowdose heparin on urinary albumin excretion in insulin-dependent diabetes mellitus. Lancet 345: 421-422

44. Meade TW, Vickers MV, Thompson SG, Stirling Y, Haines AP, Miller GJ (1985) The effect of physiological levels of fibrinogen on platelet aggregation. Thromb Res 58: 527-534

45. Donadio JV, Ilstrup DM, Holley KE, Romero JC (1988) Platelet inhibitor treatment of diabetic nephropathy: a 10year prospective study. Mayo Clin Proc 63: 3-15

46. Solerte SB, Fioravanti M (1987) Hemodynamic alterations in longterm insulin-dependent patients with overt nephropathy: role of blood hyperviscosity and plasma protein changes. Clin Nephrol 28: 138-143

47. Crowley P, Metzger J, Assaf A, Carleton RC, Merrill E, Valeri CR (1994) Low density lipoprotein cholesterol and whole blood viscosity. Ann Clin Lab Sci 24: 533-541

48. Timperley WR, Ward JD, Preston FE, Duckworth T (1976) Clinical and histological studies in diabetic neuropathy: a reassessment of vascular factors in relation to intravascular coagulation. Diabetologia 12: 237-243

49. MacRury SM, Lockhart JC, Small M, Weir AI, MacCuish AC, Lowe GDO (1991) Do rheological variables play a role in diabetic peripheral neuropathy? Diabet Med 8: 232-236

50. Ewing DJ, Martyn CM, Young RJ, Clarke BF (1985) The value of cardiovascular autonomic function test: 10 years experience in diabetes. Diabetes Care 8: 491-498

51. Plater ME, Ford I, Dent MT, Preston FE, Ward JD (1996) Elevated von Willebrand factor antigen predicts deterioration in diabetic peripheral nerve function. Diabetologia 39: $336-343$

52. Woolf AD, Wakerley G, Wallington TB, Scott DGI, Dieppe PA (1987) Factor VIII related antigen in the assessment of vasculitis. Ann Rheum Dis 46: 441-447

53. Mendall MA, Patel P, Ballam L, Strachan D, Northfield TC (1996) C reactive protein and its relation to cardiovascular risk factors: a population based cross sectional study. BMJ 312: 1061-1065

54. Thomas AE, Green FR, Kelleher CH et al. (1991) Variation in the promoter region of the beta fibrinogen gene is associated with plasma fibrinogen levels in smokers and non-smokers. Thromb Haemost 65: 487-490

55. Krolewski AS, Canessa M, Warram JH et al. (1988) Predisposition to hypertension and susceptibility to renal disease in IDDM. New Engl J Med 318: 140-145

56. Seaquist ER, Goetz FC, Rich S, Barbosa J (1989) Familial clustering of diabetic kidney disease: evidence for genetic susceptibility for diabetic nephropathy. New Engl J Med 320: 1161-1165 